\title{
An Overview of Follow-on Testing Activities of the A-3 Subscale Diffuser Test Project
}

\author{
James E. Ryan ${ }^{1}$ \\ NASA, Stennis Space Center, MS 39529
}

\begin{abstract}
An overview of NASA Stennis Space Center's (SSC) A-3 Subscale Diffuser Test (SDT) Project is presented. The original scope of the SDT Project, conducted from April 2007 to January 2008, collected data to support mitigation of risk associated with design and procurement activities of the A-3 Test Stand Project, an effort to construct a simulated altitude test facility at SSC in support of NASA's Constellation Program. Follow-on tests were conducted from May 2008 through August 2009, utilizing the SDT test setup as a testbed for additional risk mitigation activities. Included are descriptions of the Subscale Diffuser (SD) test article, the test facility configuration, and test approaches.
\end{abstract}

\section{Nomenclature}

$\begin{array}{ll}\text { AIAA } & \text { American Institute of Aeronautics and Astronautics } \\ \text { AR } & \text { Area Ratio } \\ \text { ASEE } & \text { American Society for Engineering Education } \\ \text { AMSE } & \text { American Society of Mechanical Engineers } \\ \text { CO } & \text { Carbon Monoxide } \\ \text { CO2 } & \text { Carbon Dioxide } \\ \text { CSG } & \text { Chemical Steam Generator } \\ \mathrm{GH}_{2} & \text { Gaseous Hydrogen } \\ \mathrm{GN}_{2} & \text { Gaseous Nitrogen } \\ \text { GOX } & \text { Gaseous Oxygen } \\ \text { IPA } & \text { Isopropyl Alcohol } \\ \text { JSS } & \text { J-2X Subscale Simulator } \\ \text { JTI } & \text { Jacobs Technology Incorporated } \\ \text { LH } & \text { Liquid Hydrogen } \\ \text { LOX } & \text { Liquid Oxygen } \\ \text { MSFC } & \text { Marshall Space Flight Center } \\ \text { NASA } & \text { National Aeronautics and Space Administration } \\ \text { PRD } & \text { Project Requirements Document } \\ \text { PWR } & \text { Pratt and Whitney Rocketdyne } \\ \text { SD } & \text { Subscale Diffuser } \\ \text { SDT } & \text { Subscale Diffuser Test } \\ \text { SSC } & \text { Stennis Space Center } \\ \text { SSD } & \text { Subsonic Diffuser } \\ \text { TIM } & \text { Technical Interchange Meeting } \\ \text { WSTF } & \text { White Sands Test Facility }\end{array}$

${ }^{1}$ Systems Engineer, Engineering and Science Directorate, NASA, Stennis Space Center, MS 39529 


\section{Introduction}

The original purpose of the Subscale Diffuser Test (SDT) Project, conducted at NASA's John C. Stennis Space Center (SSC) April 2007 through January 2008, was to provide performance data to support the design of the integrated A-3 Test Stand diffuser system prior to solicitation of bids for constructing it. (An overview of the originally scoped test project was presented at the 27th AIAA Aerodynamics Measurement and Ground Testing Conference [8].) Upon completion of this original series of tests, NASA recognized the value of the SDT test setup as a testbed appropriate for further A-3 risk mitigation testing. Additional test series were conceived and have been carried out since May 2008; some are still being performed as of August 2009. This paper presents an overview of these follow-on tests, including test objectives, test facility setups, and testing approaches.

\section{A. A-3 Test Stand and Diffuser}

SSC's A-3 Test Stand (See Figure 1.) will provide altitude testing capability for the new J-2X engine, which will provide propulsion to the upper stage of NASA's Project Constellation's ARES I launch vehicle. The J2X engine, currently under design and development by Pratt and Whitney Rocketdyne (PWR) under a NASA contract, is a liquid hydrogen $\left(\mathrm{LH}_{2}\right)$, liquid oxygen ( $\left.\mathrm{LOX}\right)$, gas generator cycle engine with maximum thrust capability of 294,000 lbf. Development and certification testing objectives for J-2X altitude testing at A-3 will include demonstration in near-vacuum conditions of start and restart capability, demonstration of engine performance and characterization of the nozzle extension response.

The A-3 will accomplish altitude simulation by means of an integrated test chamber-diffuser system. The airtight test chamber will enclose the $\mathrm{J}-2 \mathrm{X}$ and maintain pumped-down high-altitude atmospheric conditions during hot-fire tests. Pump-down of the test chamber will be accomplished by the 360 -foot long diffuser. The L-shaped diffuser will be constructed of carbon steel segments, approximately 12 feet in diameter. The top-most section of the diffuser, called the "rocket diffuser", widens to a diameter of approximately 15 feet to capture the rocket plume in both gimbaled and non-gimbaled orientations. Each diffuser segment will have dedicated cooling water subsystem consisting of piping fed by SSC's already-existent High Pressure Industrial Water pumping system. Pump-down of the test chamber will be accomplished by means of the diffuser's two annular steam ejectors. The steam ejectors will be driven by superheated steam supplied at a mass flow rate of $4,800 \mathrm{lbm} / \mathrm{sec}$. A dedicated chemical steam generation system, comprising a farm of 27 LOX/isopropyl alcohol (IPA) chemical steam generators (CSG), will provide the required steam flows. The design of the CSG module to be employed by the A3's steam generation system is based upon that of a CSG module which has been in use at NASA's White Sands Test Facility (WSTF) for approximately 40 years. Construction of the A-3 Test Stand is underway, and activation is scheduled for 2010.

\section{B. The Inception and Scope of the Original Subscale Diffuser Test Project}

Early in the life cycle of the A-3 project it was recognized that there were several design areas for which insufficient information existed to predict diffuser performance with any high degree of confidence. In order to avoid unnecessary cost, rather than overdesign the system, the J-2X and A-3 Project's management decided to perform testing on a subscale diffuser model in order to settle these performance issues. Marshall Space Flight Center's (MSFC) J-2X Project Office initiated and funded the SDT Project at SSC as a means to address the diffuser performance issues and mitigate the associated risk. The SDT Project entailed design and construction of subscale models of the A-3 diffuser and the associated test chamber and subsequent testing at the SSC E Test Complex. The testing would include firing of a subscale rocket engine, enclosed in the subscale test chamber, into the model diffuser; controlled injection of steam into the subscale diffuser steam ejectors; and measurement of performance parameters. 


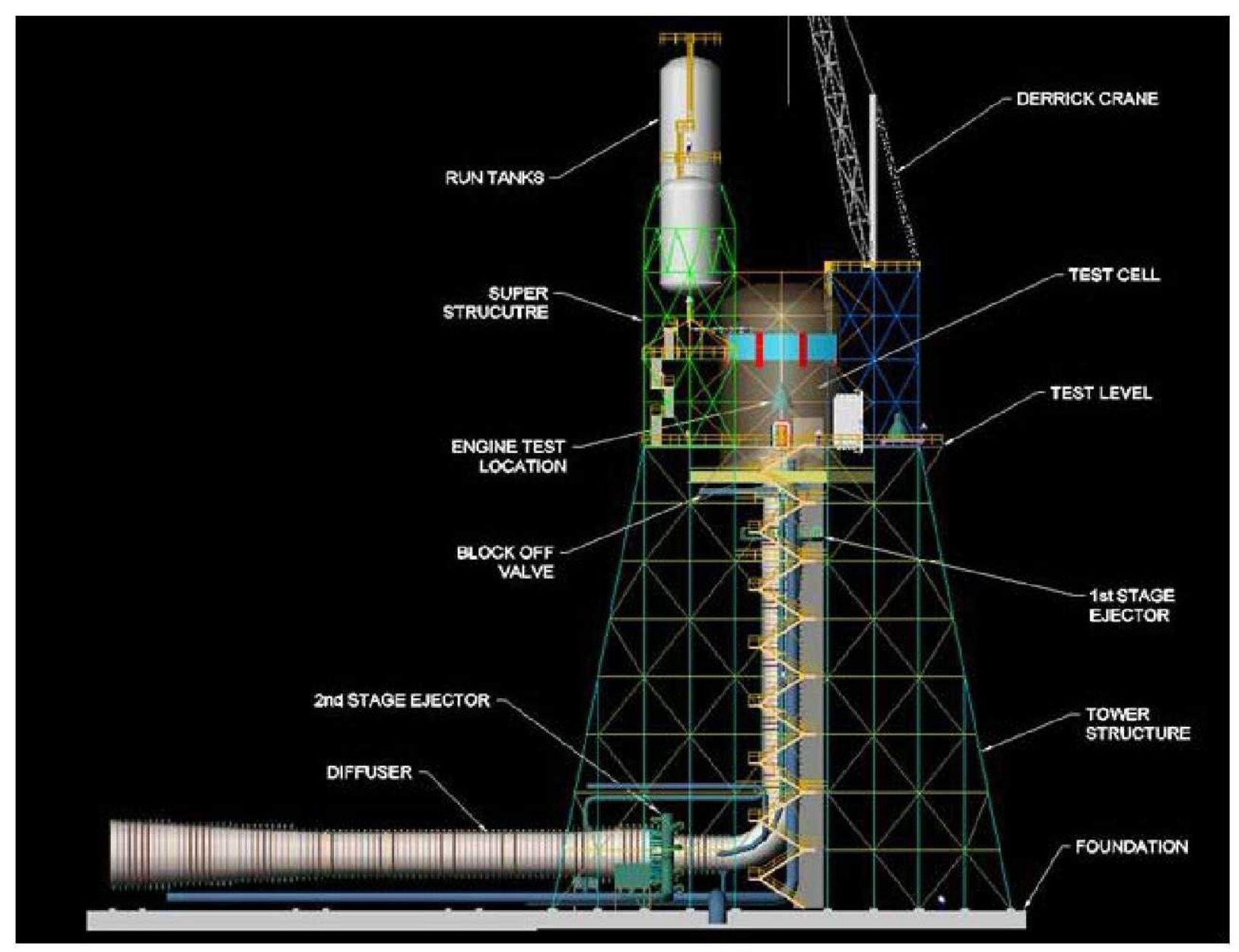

Figure 1. Graphical Depiction of A-3 Test Stand.

The primary objective of the originally defined SDT project was to provide data to support the design of the integrated diffuser system by addressing key performance issues, including: (a) adequacy of the design to pump down test chamber pressure to required levels; (b) diffuser wall heating rates; (c) pressure losses in the diffuser elbow.

\section{The SDT Project Test Article}

The Subscale Diffuser (SD) test article (See Figure 2.), a 5.783\% model of the full scale A-3 diffuser, was designed by Jacobs Technology Incorporated (JTI) under a NASA contract. It consists of the L-shaped diffuser proper, including the rocket diffuser, the two steam ejectors, and the test chamber (See Figure 3.) for enclosure of an engine during hot fire test. Unlike the full-scale diffuser, the original SD test article had no active cooling system, as this was not required to meet original test objectives. Thermal damage to the SD wasto be avoided by constraining hot fire test durations to less than $12 \mathrm{sec}$;; a firing duration of $5 \mathrm{sec}$. was calculated to be adequate for heat flux measurements required by the SDT project. The test chamber provides for $\mathrm{GN}_{2}$ secondary flow through the test chamber and into the diffuser by means of a ring purge device at the top of the chamber. The $\mathrm{GN}_{2}$ flow rate was controlled by pressure control valves located outside of the chamber. Secondary $\mathrm{GN}_{2}$ flow is used in startup and shutdown investigations. 


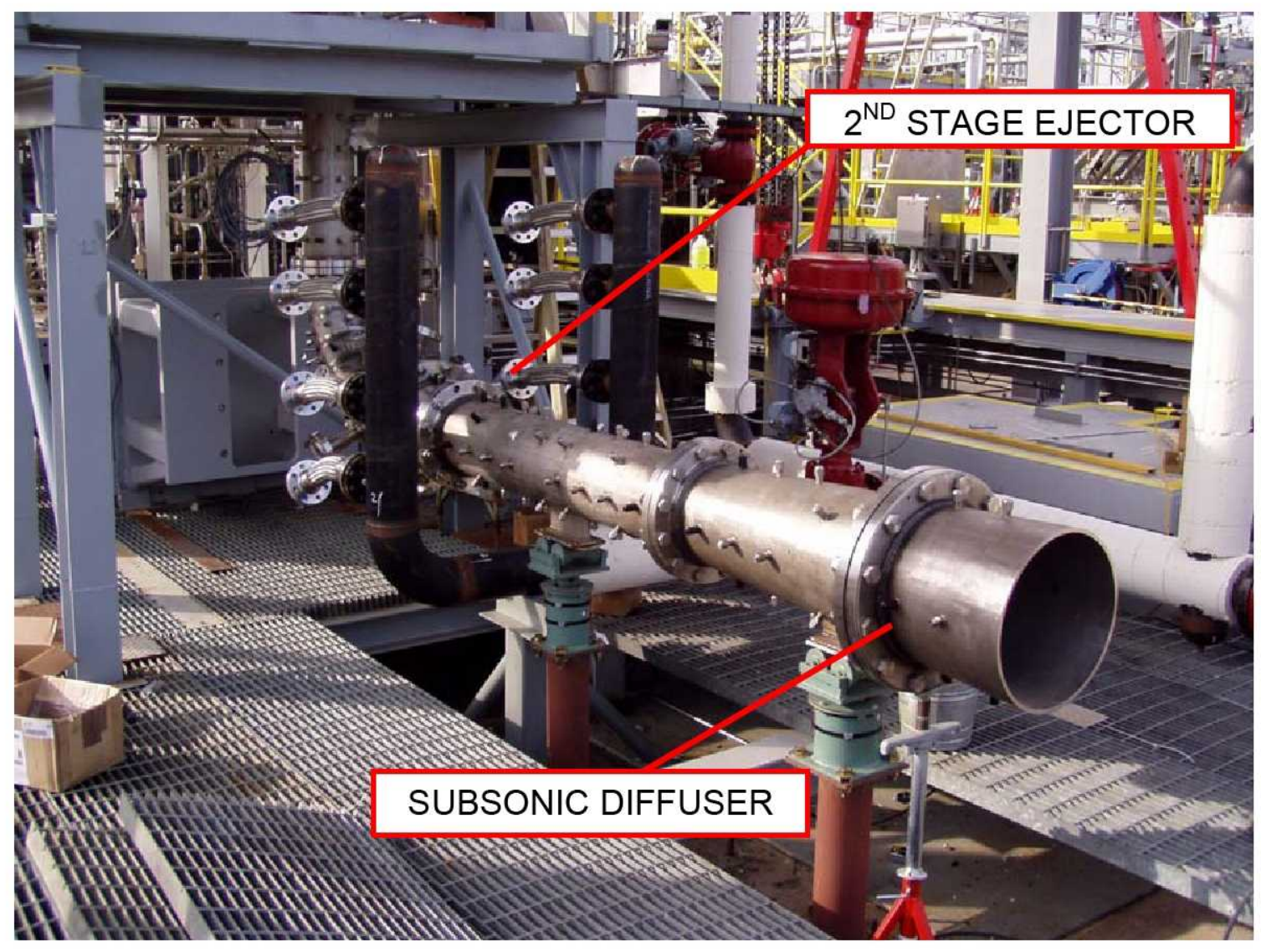

Figure 2. Subscale Diffuser Test Article.

\section{The SDT Project Test Configuration}

Testing of the SD has been performed at the SSC E-3 Test Facility. A diagram of the test configuration is presented in Figure 4. The E3 is a two-cell test stand which is suitable for component development testing of combustion devices, rocket engine components and small or subscale complete engines and boosters.

The SD is mounted in Cell 1 of E-3, oriented so as to exhaust horizontally into the atmosphere. A platform holds the test chamber in place around the topmost part (i.e., the rocket diffuser) of the SD. A small ( $1,000 \mathrm{lbf}$ of thrust) rocket engine acting as a J-2X subscale simulator (JSS) is installed inside the test chamber, mounted to fire vertically, downward into the rocket diffuser. The JSS is a water-cooled, $\mathrm{GH}_{2}$ - and LOX-propelled engine capable of approximately $1,000 \mathrm{lbf}$ of thrust.

Cell 2 of E-3 is dedicated to the operation of a chemical steam generator, which produces the steam required to drive the SD steam ejectors. Steam is ducted through the steam system piping from Cell 2 to Cell 1, where the SD is installed.

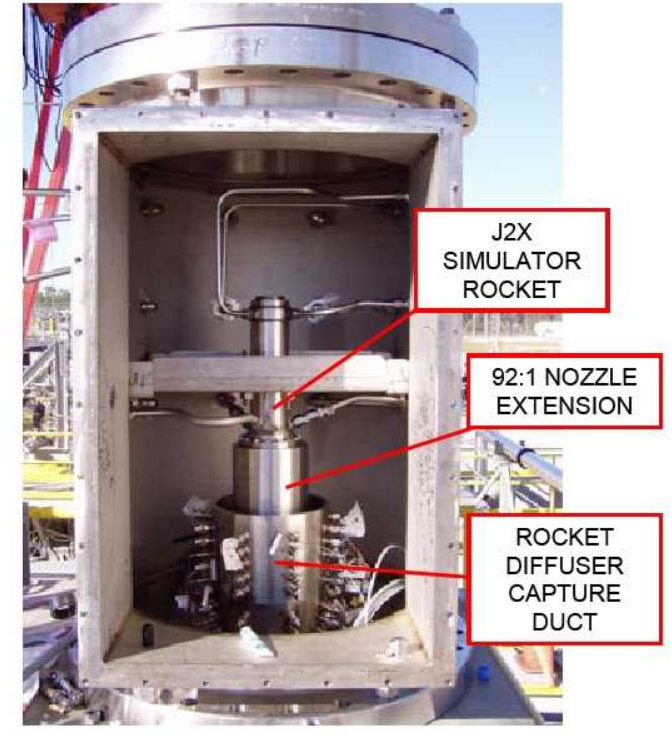

Figure 3. Subscale Test Chamber 
This steam generator is not to be confused with the WSTF-type CSG which will be used on the A-3. The E-3 Cell 2 steam generator was designed and developed at SSC specifically for the purpose of driving the SD for testing purposes. The primary components of the steam generator are a small rocket engine, nearly identical to the JSS, and a spray cooler, which quenches the rocket plume to create steam. A diagram of the steam system, which generates the steam and controls the flow to the SD steam ejectors, is provided in Figure 5.

One significant modification made to the original test configuration was the introduction of gas-gas igniters, for starting of the two rocket engines. In the original configuration an Estes-style igniter was used for ignition. This had several disadvantages, including the need to replace the igniter after each rocket firing and its tendency to introduce foreign material into the combustion chamber. These igniters were replaced with GH2-GOX spark igniters. In addition to running cleaner, these igniters provided the operational advantage of providing the ability to start the JSS multiple times during a three-minute steam run. This improvement led to cutting the number of tests needed in half.

Aside from the introduction of the gas-gas igniters, the same essential test configuration as that depicted in Figure 4 was used in the follow-on tests. In some cases modifications were made for particular tests; where that was the case, those modifications are described later in this paper.

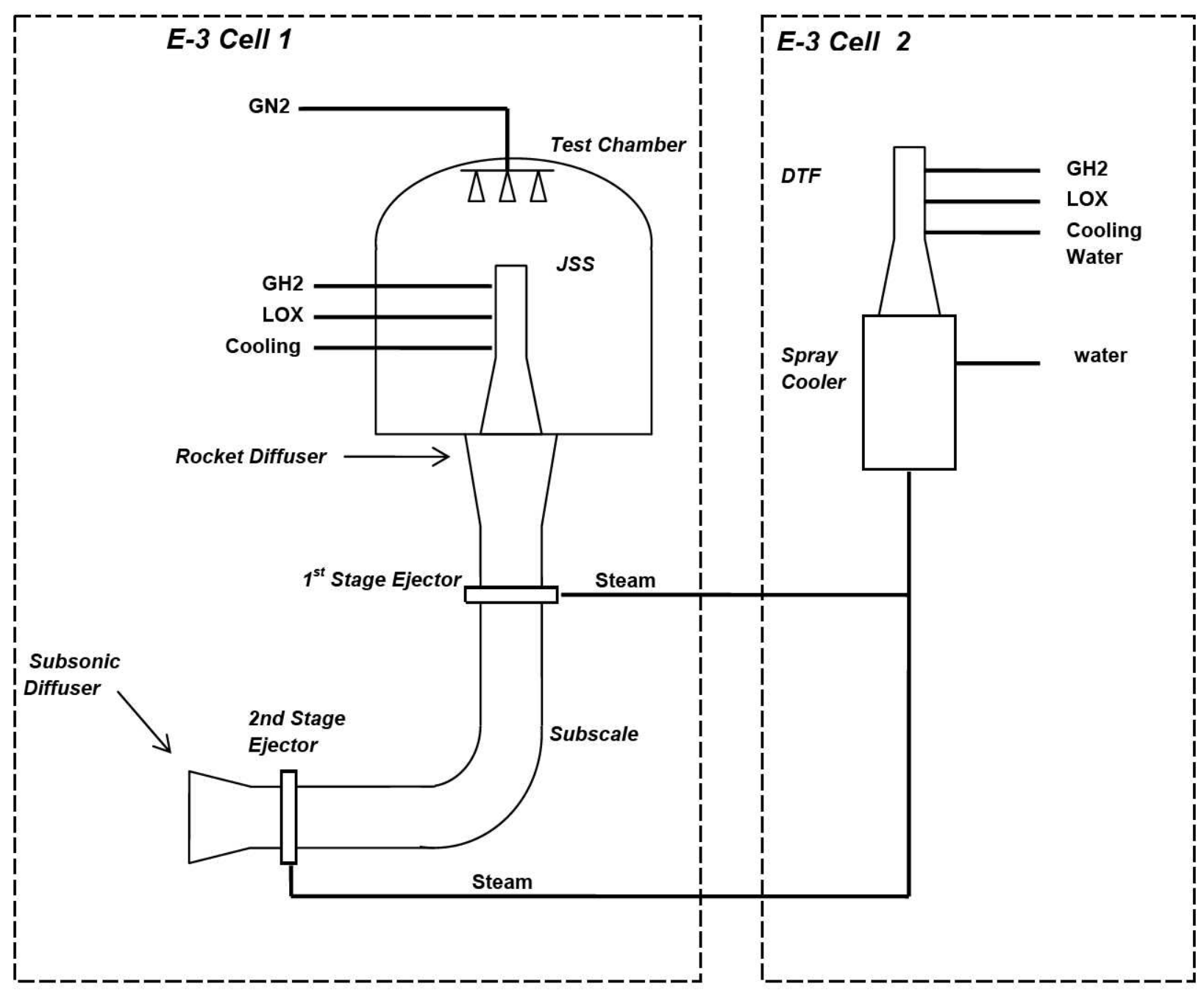

Figure 4. SDT Project Original Test Configuration. 


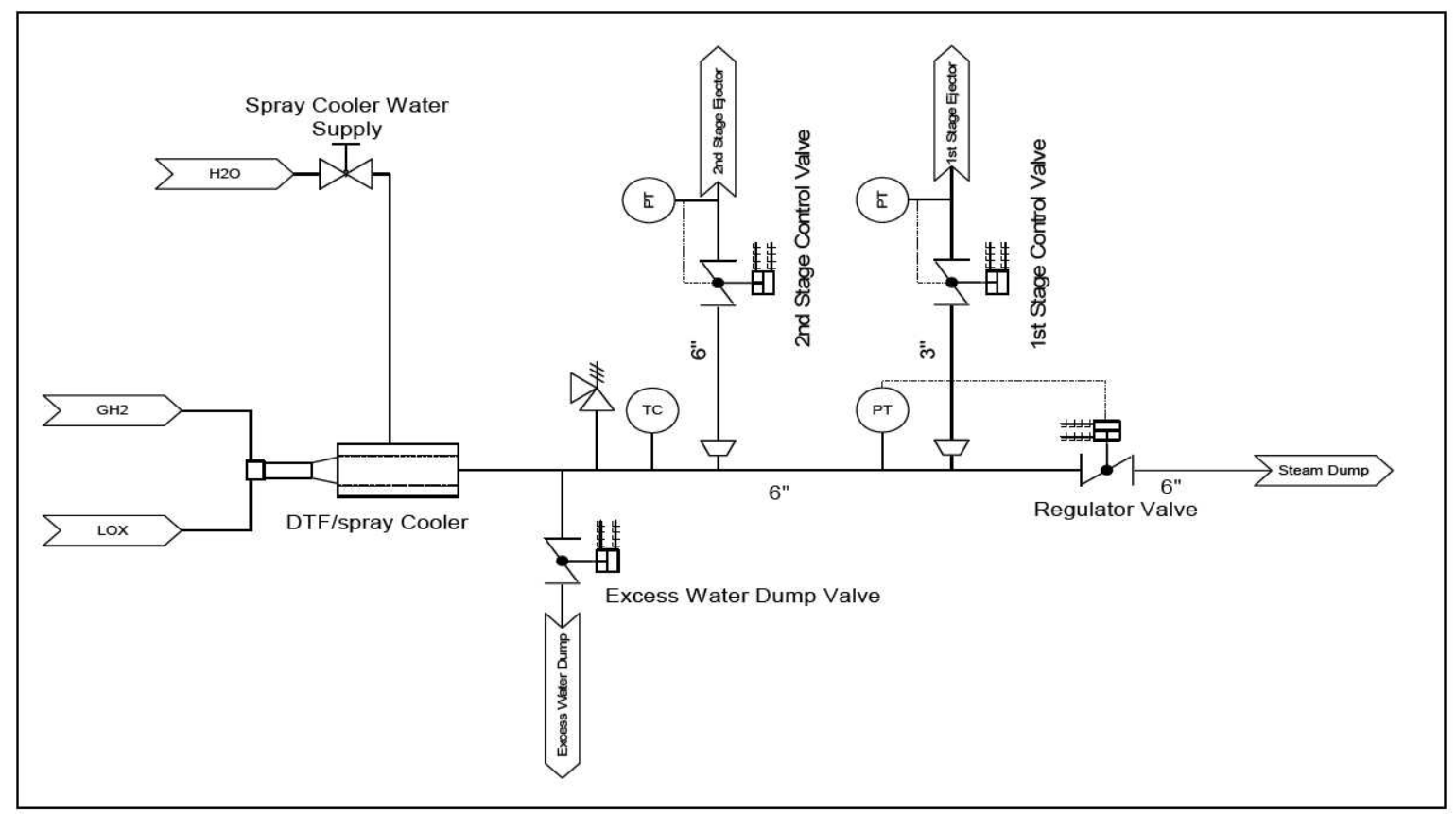

Figure 5. Diagram of E-3 Steam System

\section{Subscale Diffuser Follow-on Test Project}

\section{A. Follow-on Testing Overview}

There are eleven series of follow-on SDT tests which have been performed or are soon to be performed. The ten test series address five areas of A-3 diffuser issues: (a) performance of the diffuser, (b) test operations, (c) thermal issues, (d) afterburning, (e) acoustics. These are summarized in Table 1. Descriptions of the test series in these five categories, including discussion of test objectives, special test configurations and approaches, will be discussed below. Discussion of the specific results of these tests is beyond the scope of this paper, although some of these results may be discussed in other papers presented at the $45^{\text {th }}$ AIAA/ASME/SAE/ASEE Joint Propulsion Conference do.

\begin{tabular}{|r|l|l|c|c|}
\cline { 2 - 5 } \multicolumn{1}{|c|}{} & \multicolumn{1}{|c|}{ Test Series } & \multicolumn{1}{c|}{ Purpose/Description } & Type of Issue Addressed & Status \\
\hline 1. & $\begin{array}{l}\text { Removal of } \\
\text { Subsonic } \\
\text { Diffuser }\end{array}$ & $\begin{array}{l}\text { Determine if SD performance degrades } \\
\text { with removal of Subsonic Diffuser }\end{array}$ & Diffuser Performance & Complete \\
\hline 3. & Water Injection & $\begin{array}{l}\text { Determine max flow rate of water into } \\
\text { the diffuser possible without unstarting } \\
\text { the diffuser. }\end{array}$ & $\begin{array}{l}\text { Thermal } \\
\text { Diffuser for gimbaled rocket engine. }\end{array}$ & Complete \\
\hline 4. & Elbow Cooling & $\begin{array}{l}\text { Measure heat flux in film-cooled } \\
\text { diffuser elbow during hot fire. }\end{array}$ & Thermal & Complete \\
\hline 5. & Copper Panel & $\begin{array}{l}\text { Subject samples of heat-resistant } \\
\text { materials to high heat flux levels to }\end{array}$ & Thermal & Future \\
\hline
\end{tabular}




\begin{tabular}{|c|c|c|c|c|}
\hline & & evaluate suitability for SD elbow use & & \\
\hline 6. & $\begin{array}{l}\text { Rocket Nozzle } \\
\text { Differential } \\
\text { Pressure }\end{array}$ & $\begin{array}{l}\text { Measure pressure effects on rocket } \\
\text { nozzle during startup and shutdown of } \\
\text { SD. }\end{array}$ & Test Operations & Complete \\
\hline 7. & Stub Nozzle & $\begin{array}{l}\text { Verify that overexpansion of the rocket } \\
\text { plume outside of capture duct can be } \\
\text { prevented with } \mathrm{GN}_{2} \text { secondary flow. }\end{array}$ & Test Operations & Complete \\
\hline 8. & GOX Injection & $\begin{array}{l}\text { Determine conditions of afterburning } \\
\text { in the SD. }\end{array}$ & Afterburning & Complete \\
\hline 9. & Gas Composition & $\begin{array}{l}\text { Replicate expected gas composition of } \\
\text { CSG output in the SD and investigate } \\
\text { afterburning }\end{array}$ & Afterburning & Ongoing \\
\hline 10. & $\begin{array}{l}\text { Acoustical } \\
\text { Modeling }\end{array}$ & & Acoustics & Complete \\
\hline 11. & $\begin{array}{l}\text { Noise } \\
\text { Suppression }\end{array}$ & $\begin{array}{l}\text { Measure effect of water deluge of SD } \\
\text { exit exhaust on acoustic levels } \\
\text { downrange }\end{array}$ & Acoustics & Complete \\
\hline
\end{tabular}

Table 1. Follow-on SDT Test Series.

\section{B. Diffuser Performance Tests}

Removal of Subsonic Diffuser. A series of tests were run to measure performance of the SD with the subsonic diffuser (SSD, the last segment of the SD) removed. While the presence of the subsonic diffuser contributes to SD performance, the test would help quantify the resultant performance gain. Elimination of the subsonic diffuser from might contribute to cost savings through a simpler diffuser design, elimination of ancillary support systems, and lower operations and maintenance costs.

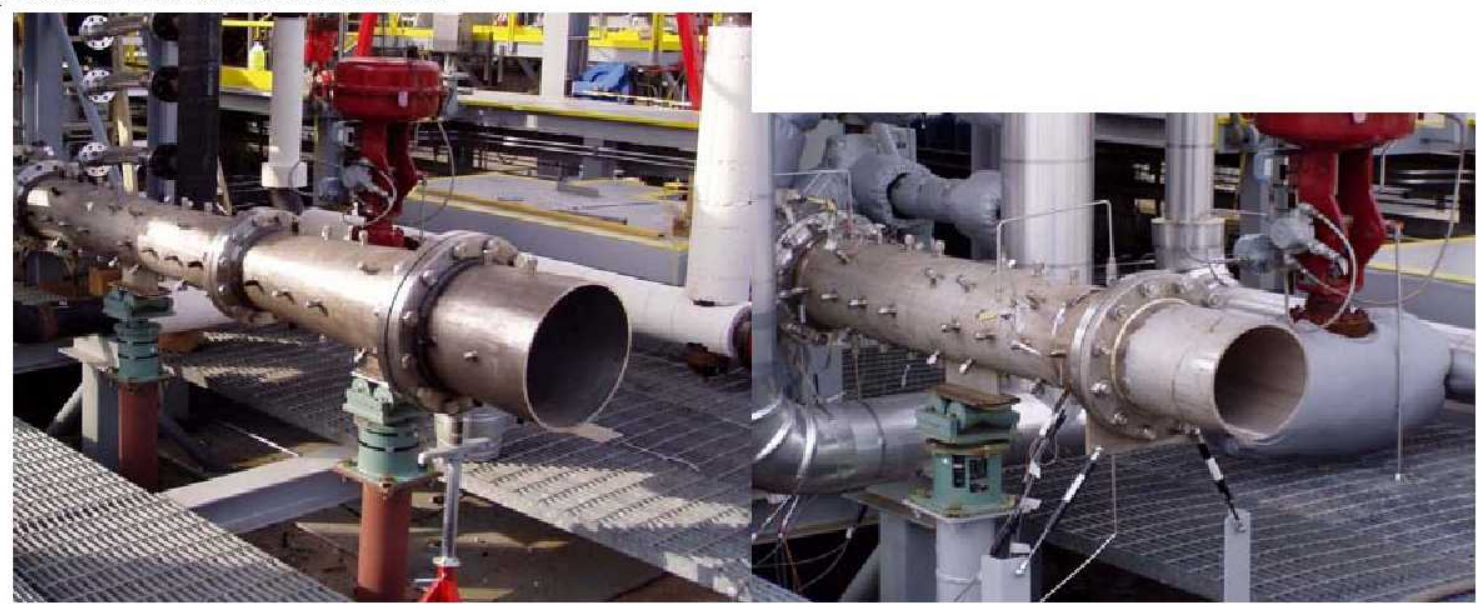

Figure 7. Normal SD configuration (left); with SSD removed (right). 
Results of these tests were compared with performance measurements of the SD in normal configuration acquired in earlier test series. It was determined that diffuser performance without the SSD would still be within minimum requirements, but would reduce available performance margin. Trade studies on possible design changes are to be performed based on the test results.

Accomplishment of these tests required the replacement of the subsonic diffuser with a straight piece of pipe (See Figure 6.) and nominal steam flow through the SD, as was done in the original performance tests. No JSS hot-fire was required. Measurements of Test Chamber pressure and $2^{\text {nd }}$ Stage Ejector pressure were acquired to judge performance.

\section{Thermal Issues Tests}

The analysis of the original scope SD test data determined heat flux levels that are to be expected in the full-scale diffuser. A number of subscale test series, described below, were devised to further study heat loading of the diffuser and to evaluate diffuser cooling systems and approaches. Two regions of particular concern were the rocket diffuser and the elbow.

Gimbal Testing. A series of tests were performed to determine heat flux levels and their distribution in the rocket diffuser during hot fire of a gimbaled rocket engine. Data acquired were used as a basis for evaluating the adequacy of the A-3 rocket diffuser design to dissipate heat during gimbaled hot fires of the J-2X.

Accomplishment of these tests required nominal steam flow through the SD and hot firing of the JSS while it was shimmed at angles of 0,3 and 7 degrees in North, South and East directions (See Figure 8.). These orientations are appropriate for modeling the rocket diffuser response over the range of J-2X testing orientations. The test series required the installation of additional thermocouples and pressure transducers in the rocket diffuser plume impingement area for improved spatial resolution of the data.

Water Injection. A series of water injection tests were performed to determine at what mass flow rate of injected water the diffuser would unstart (i.e., the pump-down of the test chamber would fail). Data collected from this test would contribute to determination of the maximum flow rate available to the diffuser's cooling system for the purpose of regulating heat. A secondary objective was to determine the effectiveness of this injection method on cooling the diffuser elbow.

Analysis of the test results determined that a sufficient level of water flow was available to to dissipate the heat in the

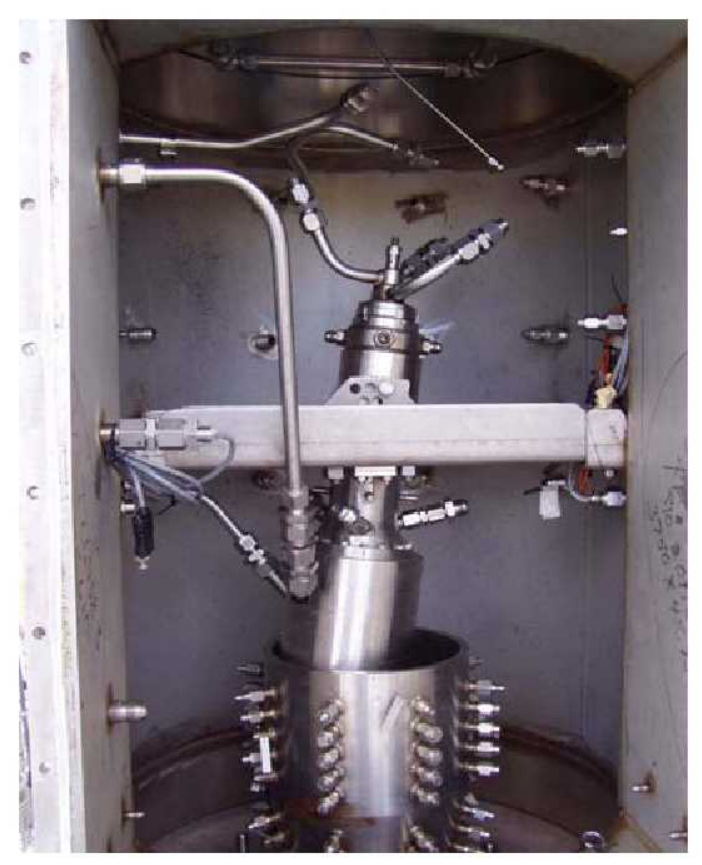
diffuser, although the effectiveness of the cooling depended on the manner in which the water is applied. In particular, for elbow cooling to adequate water would have to flow as a film inside the elbow.

These tests were accomplished through the injection of water into the diffuser upstream of the elbow through instrumentation ports (See Figure 9.). The angle of injection was normal to the direction of diffuser gas flow. Water injection was performed simultaneously with firing of the JSS and during nominal steam flow. The tests measured test chamber performance under varying injected water mass flow rates and for various combinations of $1^{\text {st }}$ and $2^{\text {nd }}$ stage ejector valve positions.

Elbow Cooling Tests. Two additional test series were performed to assess the adequacy of elbow cooling. The first performed elbow cooling with subscale version of the then-current full-scale design water injector ring. The 
second did the same with a newly designed subscale film-cooled injector ring. The decision to perform the second test series with its associated injector ring was made after the first test series showed less than desired performance.

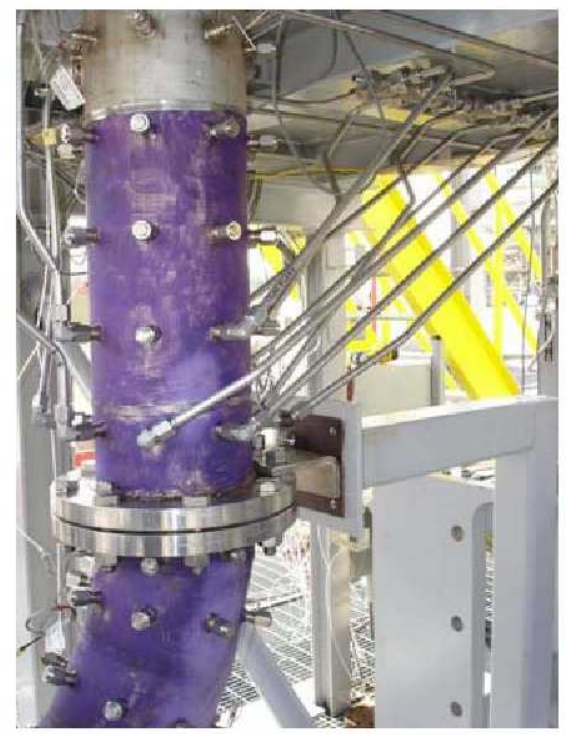

Figure 9. Water injection upstream of the elbow.

The former design injected water uniformly in a direction generally

parallel to the diffuser gas flow, although not necessarily in a film-cooling fashion, as did the latter.

As with the water injection tests, for the elbow cooling water flow was performed during nominal steam flow and simultaneously with the firing of the JSS. The tests measured test chamber performance under varying injected water mass flow rates and for various combinations of the $1^{\text {st }}$ and $2^{\text {nd }}$ stage ejector valves. A number of thermocouples and pressure transducers were added to the elbow to provide more spatial density to the measurements.

Panel Testing. A series of tests have been devised to test samples of copper panels to be used in construction of the full-scale elbow. The panels have small diameter cooling channels throughout. There is a concern that operation of the elbow at high heat fluxes will result in the formation of oxidation or scales in the channels, which could decrease their thermal conductivity. The tests will flow water through the channels and subject copper panels similar to those to be used in the diffuser elbow to heat fluxes expected to be seen during $\mathrm{J}-2 \mathrm{X}$ testing.

The tests will be accomplished by removing the spray cooler of the steam generator. The copper panel will be mounted downstream of the steam generator thruster and impacted by the plume of the thruster. The panel will be mounted at the angle and distance required to receive the required heat flux. Water will be flowed through the cooling channels. Post-test inspections will determine the tendency to oxidize or scale. Prior to testing, a thermocouple-instrumented calibration panel will be tested to determine angle and distance to achieve the required heat fluxes.

\section{Test Operations Issues}

Rocket Nozzle Differential Pressure. Of particular concern to NASA test engineers is the possibly damaging effects of A3 diffuser pressure transients on the fragile J-2X nozzle. Such transients might arise from startup or shutdown of the steam generation system, from failure of one or more CSGs or from failure of one of the ejector valves during normal test operations.

A series of subscale tests were run to simulate transient-causing events and to measure their effects on a JSS nozzle. To accomplish these tests an instrumented nozzle was constructed and attached to the JSS. (See Figure 10.) The nozzle had eight instrumentation ports located at various distances from the JSS exit plane. In each port was installed a high-frequency differential pressure transducer.

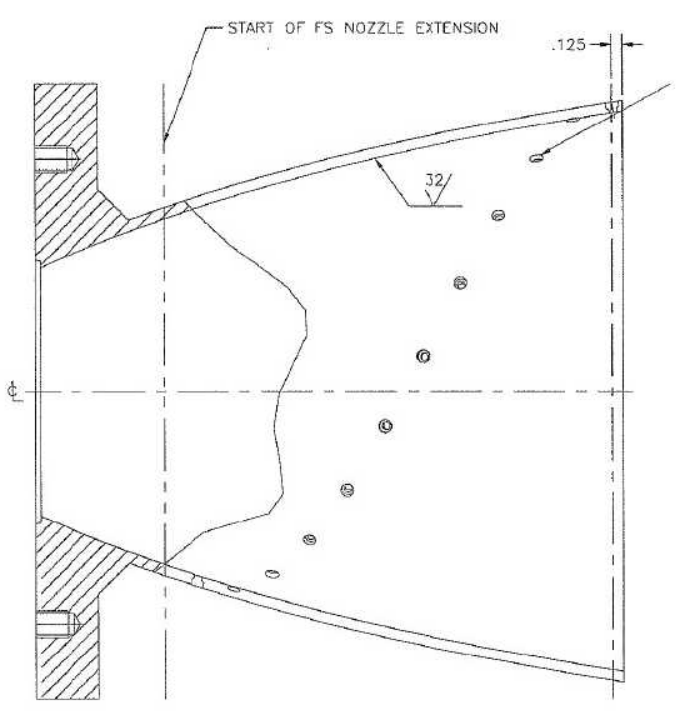

Differential pressures to simulate startup and shutdown transients that might be seen at the nozzle were induced by flowing steam through the SD and slewing the ejector valves

Figure 10. Instrumented rocket nozzle. 
open and closed at various pre-determined rates. For simulation of failure modes the ejector valves were opened and closed at specific intervals at the fastest rate possible to effect the sudden loss of discrete amounts of steam pressure. There were no JSS hot fires run for these tests.

Stub Nozzle. Several tests were run with a "stub nozzle" [a 59:1 are ratio (AR) nozzle, as opposed to the normal 92:1 AR nozzle] installed on the JSS to verify that overexpansion of the rocket plume outside of the capture duct can be prevented with $\mathrm{GN}_{2}$ secondary flow. The ability to control overexpansion will provide flexibility to test operations during full-scale test operations.

To accomplish the test the JSS with stub nozzle was fired under nominal steam flow and with $\mathrm{GN}_{2}$ secondary flow into the test chamber. This procedure was repeated for various $\mathrm{GN}_{2}$ flow rates. Containment of the plume within the rocket diffuser was determined by analysis of test chamber pressures and pressure and temperature measurements in the SD.

\section{E. Afterburning Investigations}

GOX Injection. GOX injection tests were performed to investigate the amount of afterburning of excess rocket fuel in the diffuser. While the J-2X tends to run fuel-rich, the WSTF CSG is expected to produce some level of GOX in its steam. There is some concern that the combination of the two might produce afterburning. Excessive afterburning might result in facility unstarting and in excessive heat transfer rates, especially downstream of the $2^{\text {nd }}$ stage ejector.

The subscale GOX injection tests injected GOX into the diffuser under JSS hot fire and nominal steam flow conditions. During these tests, since the JSS also tends to burn fuel-rich, an opportunity exists for afterburning. The amounts of GOX injected ranges up to the mass fraction of GOX expected to occur in the steam of the WSTF CSG $(6 \%)$. GOX injection was accomplished by means of an injection ring installed upstream of the diffuser elbow. The GOX injection tests resulted in a significant amount of afterburning and diffuser unstarting, even at GOX levels significantly lower than the predicted $6 \%$. Based on these results, the decision was made to perform the gas composition tests, discussed below, to further investigate the possibility of afterburning.

Gas Composition Tests. The intent of the gas composition tests is to more accurately duplicate the gas composition of the WSTF CSGs and investigate the afterburning issue. The steam produced be the WSTF CSGs, in addition to GOX and excess IPA, contains $\mathrm{CO}$ and $\mathrm{CO}_{2}$, possibly in high enough quantities to impact the likelihood of afterburning or unstarting.

As existing estimates of WSTF CSG gas composition are regarded to be questionable, tests to determine the actual gas composition of steam from a WSTF CSG were performed on one such CSG recently under test at SSC. These mass fraction ratios will be duplicated in the SD to perform the afterburning investigations.

In order to accurately reproduce in the SD the gas composition to be seen at the A-3 stand, a number of modifications are being made to the the E-3 test configuration. First, the SSC steam generator has been modified to burn isopropyl alcohol instead of GH. Second, gas injection systems have been designed to inject small amounts of $\mathrm{CO}, \mathrm{CO}_{2}$ and $\mathrm{GH}$ into the diffuser so that the composition of the SD steam can be trimmed as required. Injection will be achieved by means of rings similar to that used for GOX injection. As with GOX injection tests, required amounts of gases will be injected into the diffuser under JSS hot fire and nominal steam flow conditions.

\section{F. Acoustics Tests}

It is known that noise levels produced by A-3 altitude testing will be extremely high. Corrective measures to dampen these levels are desired, if not required. Follow-on tests have been performed for the purpose of modeling the acoustical propagation downrange from the SD and to assess the effectiveness of a water deluge approach to noise suppression. Results of these tests will be used to address the noise issue at A-3. 
Acoustical Modeling. Measurements of far-field acoustical directivity have been made during a number of SD follow-on tests for validation of an acoustical model. For this purpose free-field microphones were placed at various distances normal to the exit plane of the SD and along two 90 degree arcs at distances of 91 and 190 feet.

Noise Suppression. A series of noise suppression tests were run to determine the effectiveness of a water deluge system at the exit of the SD for this purpose. Measurements taken during normal hot fires for acoustical modeling purposes were used to serve as a baseline for comparison with similar measurements taken during these tests.

Analysis predicted that water deluge would not have any impact on the diffuser performance.

These tests employed a water deluge system which injected water into the exhaust exit jet. Several water deluge rings were constructed, each with different numbers of water exit holes around the ring, and each with holes of different diameters.

A noise suppression test entailed a hot-fire of the JSS during nominal steam flow with one of the deluge rings installed near the SD exit injecting water into the plume. Water from the ring was injected into the exhaust plume at a defined angle, at a defined distance from the exit plane and at a defined flow rate. Free-field microphones were placed at various locations down range of the diffuser and measurements taken on a dedicated data acquisition system, similarly as was done for acoustical modeling. Analysis of the noise suppression data is ongoing.

\section{Conclusion}

An overview of the original SDT Project conducted at SSC was presented, including descriptions of the SD test article; the test configuration; the test objectives; the test plan; and approaches to testing was presented. The original scope of the SDT Project was completed successfully. Since completion of the original scope of the SDT test configuration has served as a testbed for follow-on testing, which was described herein. While details of test results were not discussed herein, other papers presented at the $45^{\text {th }}$ AIAA/ASME/SAE/ASEE Joint Propulsion Conference do.

\section{References}

[1] Jacobs Technology Inc. A-3 Design Validation Testing PRD/TIM. April 2007.

[2] Jacobs Technology Inc. Status of A-3 Elbow. 8 October 2008.

[3] NASA, John C.Stennis Space Center. A3 Altitude Test Facility Project Plan. PP-A3TF-1901.June 2007.

[4] NASA, John C.Stennis Space Center. Propulsion Test Directorate E3 Facility Capabilities Document. E3FCD-001. December 2002.

[5] NASA, John C.Stennis Space Center. Subscale Diffuser Test Project Delta Test Readiness Review. 22 August 2008. 2009

[6] NASA, John C.Stennis Space Center. Subscale Diffuser Test Project Delta Test Readiness Review. 12 June

[7] National Aeronautics and Space Administration. NASA's Exploration Systems Architecture Study Final Report. NASA-TM-2005-214062. November 2005.

[8] Ryan, et al. An Overview of the A-3 Subscale Diffuser Test Project, June 2008, Proceedings, 27th AIAA Aerodynamics Measurement and Ground Testing Conference, 